\title{
Sudjelovanje učitelja osnovnih škola u aktivnostima Erasmus+ programa*
}

\author{
Tea Pavičić Zajec \\ I. osnovna škola Varaždin \\ Kralja P. Krešimira IV. 10, 42000 Varaždin \\ tea232pavi@hotmail.com
}

\author{
Jelena Bistrović \\ Osnovna škola "Braća Radić" \\ Miklinovec 6a, 48000 Koprivnica \\ anelej87@gmail.com
}

\section{Sažetak}

Erasmus+ najveći je program Europske unije u području obrazovanja, osposobljavanja, mladih i sporta koji nudi brojne mogućnosti za učenike i odgojno-obrazovne ustanove uključene u obrazovanje, osposobljavanje i sport. Vodeći se pretpostavkom da su učitelji nedovoljno informirani te da većina njih nije sudjelovala u Erasmus+ projektima, cilj ovog rada bio je ispitati informiranost i sudjelovanje učitelja osnovnih škola sjeverozapadne Hrvatske u sklopu Erasmus+ programa. Istraživanje je provedeno školske godine 2017./2018. na uzorku od 115 odgojno-obrazovnih djelatnika iz 15-ak osnovnih škola iz područja sjeverozapadne Hrvatske. lako 49,6\% ispitanika smatra kako je dobro upoznato s Erasmus+ programom $i$ mogućnostima koje koje se nude učiteljima osnovnih škola, rezultati istraživanja pokazuju da većina, njih 81,6\% ispitanika dosad nije sudjelovala u Erasmus+ programima, kao ni u eTwinning mobilnostima ili TCA seminarima organiziranim od strane Agencije za mobilnost i programe Europske Unije. Od ukupnog broja ispitanika, svega 18,4\% učitelja sudjelovalo je u Erasmus KA1 ili KA2 projektima, a 18,3\% na TCA seminarima ili eTwinning mobilnostima.

Ključne riječi: inovacije u obrazovanju mobilnost osoblja; strateška partnerstva; školska razmjena.

\section{Uvod}

Erasmust program preteča je LLP programa (Lifelong Learning Program) koji je bio osnovan 2007 godine s ciljem razmjene iskustava učenja, razvoja obrazovanja i osposobljavanja diljem Europe. Tijekom rada LPP programa studenti, učenici i učitelji osposobljavali su se i usavršavali kroz sljedeća četiri potprograma:

- Comenius za škole

- Erasmus za visoko obrazovanje

- Leonardo da Vinci za strukovno obrazovanje

- Grundtvig za obrazovanje odraslih (European Commission (2006) 
Republika Hrvatska punopravno se uključila u Program za cjeloživotno učenje (2007.-2013.), program Europske unije u području obrazovanja i osposobljavanja. Do završetka navedenog programa na svim razinama obrazovanja proveden je 1.691 projekt ukupne vrijednosti 23,6 milijuna eura, a program je obuhvatio ukupno 13.884 sudionika koji su imali priliku učiti, osposobljavati se $i$ usavršavati $u$ inozemstvu. $U$ sklopu potprograma Comenius koji je bio namijenjen dionicima u odgoju i općem obrazovanju, provedeno je 717 projekata, a u sklopu potprograma Leonardo da Vinci provedeno je 327 projekata (Agencija za mobilnost i programe Europske unije, 2016).

Od 2014. godine LLP program nastavlja svoj rad u okviru novoga Erasmus+ programa čiji je planirani rok trajanja do 2020. godina. Program je podržan od strane Europske Unije, a za njegovu provedbu u Republici Hrvatskoj zadužena je Agencija za mobilnost i programe Europske Unije. Danas, svi spomenuti potprogrami spojeni su u jedan program naziva Erasmust čiji je cilj pridonijeti strategiji Europa 2020 za povećanje zaposlenosti, istraživanja, razvoja i obrazovanja i smanjenje siromaštva i socijalne isključenosti. Nadalje, cilj Erasmus+ programa je i promicanje održivog razvoja svojih partnera u području visokog obrazovanja i doprinositi postizanju ciljeva Strategije mladih EU.

Vodeći se pretpostavkom da su učitelji nedovoljno informirani te da većina njih nije sudjelovala u Erasmus+ projektima, cilj ovog rada je svim odgojno-obrazovnim djelatnicima pružiti uvid u dobrobiti Erasmus+ programa te ispitati informiranost i sudjelovanje učitelja osnovnih škola sjeverozapadne Hrvatske u sklopu Erasmus+ programa. U sklopu programa Erasmus+ do 2016. godine provedeno je 231 projekt u području odgoja i općeg obrazovanja te 114 projekata u području strukovnog obrazovanja i osposobljavanja. Ti su projekti od posebne koristi svim odgojno-obrazovnim ustanovama jer im kroz nove, inovativne prakse, mobilnosti u inozemstvu i učenje od europskih kolega te relevantne projektne rezultate pomažu u premošćivanju odgojno-obrazovnih izazova, jačanju stručnih timova i cijele ustanove te osuvremenjivanju odgojno-obrazovnih metoda (Agencija

za mobilnost i programe Europske unije, 2016).

\subsection{Erasmus+ za škole}

Glavni cilj Erasmus+ programa usmjeren je jačanju znanja i vještina te zapošljivosti europskih građana, kao i unaprjeđivanju obrazovanja, osposobljavanja te rada u području mladih $\mathrm{i}$ sporta. Posebno je usmjeren povezivanju obrazovanja, osposobljavanja i sektora mladih $\mathrm{s}$ poslovnim sektorom, te je otvoren za njihove zajedničke projekte (Agencija za mobilnost i programe Europske unije (n.d.)).

Osim što program Erasmus+ može svakoj ustanovi osigurati novac i priliku da se uključi u međunarodne aktivnosti, u Erasmus+ praktičnom vodiču za ravnatelje i stručne timove u školama, navodi se pet glavnih razloga za uključivanje škola u Erasmus+ program:

- unapređivanje podučavanja i učenja

- širenje obzora učenika

- omogućavanje stručnog usavršavanja

- poboljšanje statusa škole

- povezivanje s dionicima

Erasmus+ program nudi školama mogućnost sudjelovanja u KA1 i KA2 aktivnostima. KA1 program potiče mobilnost osoblja i učitelja boravak u drugim školama s ciljem stjecanja prakse (job shadowing) ili tečajevi u inozemstvu. Također, ta aktivnost omogućuje školama ugošćivanje odgojno-obrazovnih djelatnika iz drugih škola koje sudjeluju u programu. Za prijavu u KA1 program, od škola se traži da napišu "Europski razvojni plan" koji bi trebao objasniti viziju školu i potrebe planiranih aktivnosti mobilnosti. Prijava može sadržavati različite aktivnosti tijekom jedne do dvije godine. Ukupni iznosi financiranih KA1 projekata iz programskog razdoblja (2014.-2017.) iznosi 1.926.097 eura, a posebno je važno istaknuti da se iznos sredstava namijenjenih za KA1 projekte periodički povećava iz godine u godinu, čime se povećava i broj financiranih projekata. $^{1}$ Prema statistikama

\footnotetext{
1 Ukupni iznos financiranih KA1 projekata za posljednje tri godine (2015. - 382.087eura, 2016. - 407.844 eura, 2017. 696.482 eura)
} 
Agencija za mobilnost i programe Europske Unije, u programskom razdoblju (2014.-2017.) u Republici Hrvatskoj financirano je ukupno 108 Erasmus KA1 projekata u području odgoja i općeg obrazovanja (2014. godine - 22; 2015. godine - 19; 2016. godine - 29; 2017. godine - 38).

Cilj KA2 aktivnosti je stvaranje strateškog partnerstva - projekti na kojima rade različite organizacije ali sa zajedničkim ciljem. KA2 program omogućava projektnim partnerima razmjenu osoblja i učenika ili razvoj novih i inovativnih ideja (proizvoda). Prioritetne projektne teme objavljuju se svake godine $u$ okviru natječaja Erasmus+. Projektne aktivnosti u području KA2 podrazumijevaju kratke razmjene (u trajanju od 3 dana do 2 mjeseca) i duge razmjene za učenike srednjih škola (od 2 do 12 mjeseci).

Postoje tri vrste strateškog partnerstva unutar KA2 programa:

1. školska razmjena - za škole koje žele uspostaviti prvi kontakt u razmjeni učenika i učitelja, fokus je na mobilnosti uz jednostavnu prijavu, u ovoj vrsti partnerstva može sudjelovati 2-6 škola, trajanje projekta je 1 do 2 godine, a maksimalna financijska potpora je 99000 eura godišnje.

2. razmjena dobre prakse - omogućuju školama širenje njihove međunarodne mreže kroz suradnju s različitim partnerima kao što su mlade organizacije, sveučilišta, poduzeća, ali i druge škole, maksimalna financijska podrška u ovoj vrsti partnerstva je 450000 eura, u projekt moraju biti uključene minimalno tri organizacije (maksimalnog ograničenja nema) s ukupnim trajanjem projekta od 1 do 3 godine.

3. podržavanje inovacija - ova vrsta partnerstva nudi priliku za razvoj, testiranje i prijenos inovativnih proizvoda ili metode, da bi se postigli ciljevi, projekti mogu zatražiti dodjelu bespovratnih sredstava za rad na specifičnim materijalima, uz dodatna sredstva za promicanje rezultata, u ovoj vrsti partnerstva također moraju sudjelovati minimalno tri organizacije (bilo koje) u trajanju od 1 do 3 godine, maksimalna financijska podrška u ovoj vrsti partnerstva je 450000 eura.
Ukupni iznos financiranih Erasmus KA2 projekata u Republici Hrvatskoj u području odgoja i općeg obrazovanja za programski period 2014.2017. iznosi 7.659.737. eura, a samo u 2017. godini za KA2 projekte izdvojeno je 2.754.613 eura što je skoro dvostruko više od 2016. godine (1.715.120 eura). Sukladno tim podacima, dosad je ukupno financirano 253 Erasmus KA2 u području odgoja i općeg obrazovanja Republike Hrvatske (Agencija za mobilnost i programe EU, 2018).

\subsection{Primjer dobre prakse}

Polazeći od pretpostavke da odgojno-obrazovne ustanove nedovoljno iskorištavaju sredstva iz EU fondova i sudjelovanje u Erasmus projektima zbog nedovoljne informiranosti i neznanja, želja nam je kroz primjer dobre prakse ukazati na sve dobrobiti i koristi koje organizacija, a posebno njeni učenici imaju sudjelovanjem u Erasmus+ projektima. I. osnovna škola Varaždin ${ }^{2}$ aktivno je počela sudjelovati u Erasmus+ programima od 2014. godine te trenutno provodi ukupno četiri Erasmus+ projekata (Erasmus KA1 i tri Erasmus KA2). ${ }^{3}$ Škola ima ukupno 53 zaposlenika te 481 učenika. Zahvaljujući projektnim aktivnostima, gotovo $80 \%$ učitelja upoznato je s mogućnostima koje nudi Erasmust program, a $28 \%$ učitelja sudjelovalo je u međunarodnim usavršavanjima u sklopu Erasmus KA1 programa, aktivnosti transnacionalne suradnje ili eTwinning mobilnosti. Od 2016. godine, škola surađuje s partnerima iz Slovenije, Poljske, Austrije, Grčke, Švedske, Italije i Španjolske čije su škole posjetili i naši učenici. U sklopu KA2 programa dosad je ukupno 20 učenika škole sudjelovalo u aktivnostima školske razmjene i razmjene dobre prakse u Švedskoj, Italiji i Poljskoj, a još toliko učenika putovati će u Sloveniju, Autriju i Grčku.

\footnotetext{
${ }^{2}$ http://os-prva-vz.skole.hr/erasmus_kutak

3 Erasmus KA1 - Modernizacija rada i osuvremenjivanje nastavnog procesa usavršavanjem zaposlenika I. OŠ Varaždin u području primjene IKT-a, 2016.-2018. Erasmus KA2 - Ukrotimo kompetence 21. stoletja-Slovenija-Hrvatska, 2016.-2019. Erasmus KA2 - Science Technology Art Engineering Mathematics Laboratory-Italija-Švedska-Hrvatska, 2016.-2018. Erasmus KA2 - Connected with the Environment - PoljskaAustrija-Grčka-Slovenija-Hrvatska, 2017.-2019.
} 
Zahvaljujući projektnim aktivnostima, I. osnovna škola Varaždin uvela je inovativne načine poučavanja korištenjem IKT tehnologije te osigurala za učenike tablet računala, pametne ploče i 3D printer. Sudjelovanje u Erasmus KA1 projektu Modernizacija rada i osuvremenjivanje nastavnog procesa usavršavanjem zaposlenika I. OŠ Varaždin u području primjene IKT-a rezultiralo je unaprijeđenjem i podizanjem IKT kompetencija kod $68 \%$ učitelja škole, a u tijeku je i razvoj novih modula obrazovanja koji će biti popraćeni priručnicima za učitelje razredne i predmetne nastave. Iznos bespovratnih sredstva koje je škola dobila za sudjelovanje u navedenim projektima $\mathrm{i}$ realizaciju projektnih aktivnosti iznosi 103,895 eura, a rezultati naših aktivnosti prepoznati su i diljem Europe. Škola je bila odabrana od strane Španjolskih partnera te je sudjelovala $\mathrm{u}$ job shadowing aktivnosti u sklopu koje su učitelji španjolskog jezika učili na našim primjerima kako koristiti obrazovne IKT alate u nastavi.

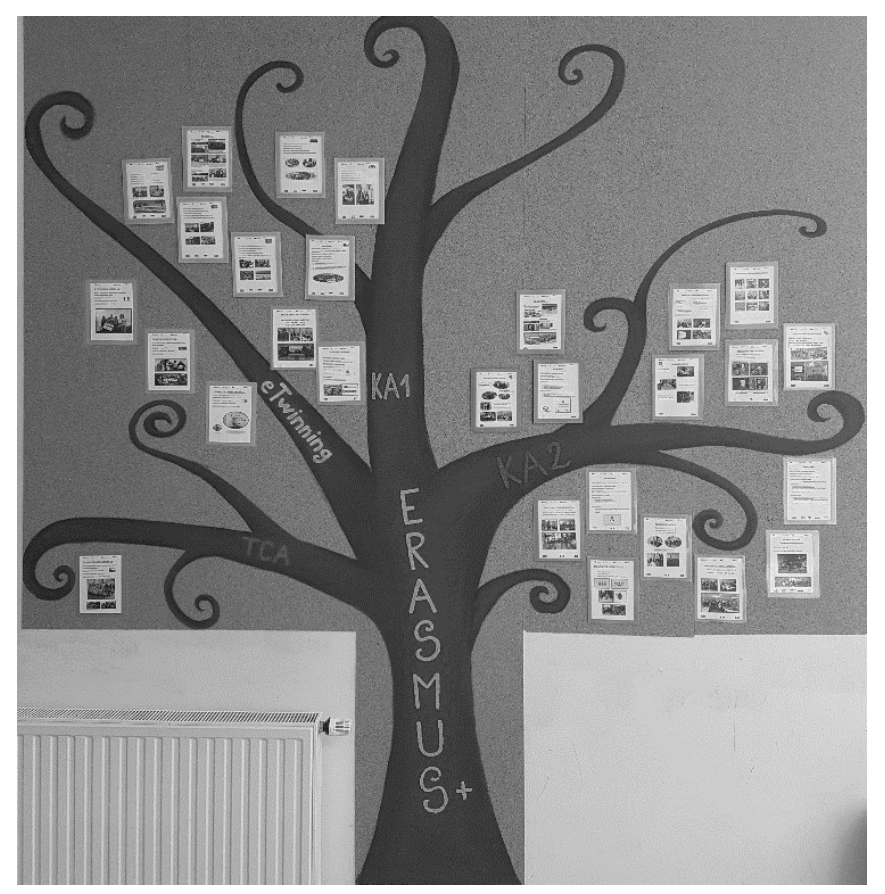

Slika 1. Erasmus drvo I. OŠ Varaždin

\section{Metodologija}

\subsection{Opis uzorka}

Istraživanje čiji je cilj ispitati informiranost i sudjelovanje učitelja osnovnih škola sjeverozapadne Hrvatske u sklopu Erasmus+ programa provedeno je školske godine 2017./2018. a uzorak su činili učitelji osnovnih škola sjeverozapadne Hrvatske: I. OŠ Varaždin, II. OŠ Varaždin, IV. OŠ Varaždin, V. OŠ Varaždin, VI. OŠ Varaždin, OŠ Cestica, OŠ Đuro Ester
Koprivnica, OŠ „Braća Radić“, Koprivnica, OŠ Pribislavec, OŠ Ivanovec, OŠ Ivana viteza Trnskog, OŠ Kalnik, OŠ Grigor Vitez, Žabno, OŠ Petrijanec, Centar za odgoj i obrazovanje Krapinske Toplice.

Uzorak je činilo ukupno 115 ( $N=115)$ odgojnoobrazovnih djelatnika od čega 47 učitelja razredne nastave $(40,9 \%), 54$ učitelja predmetne nastave (47\%), 6 ravnatelja $(5,2 \%), 3$ pripravnika/stručno osposobljavanje/asistent (2,6\%), 1 učiteljica u produženom boravku $(0,9 \%)$ te 3 pedagoga/defektologa/psihologa (2,6\%) (Grafikon 1). 
Većina ispitanika $(\mathrm{N}=45,39,1 \%)$ ima trenutni radni staž do 10 godina (Grafikon 2). Otprilike podjednaki broj ispitanika ima trenutni radni staž od 10 do 20 godina ( $\mathrm{N}=31,27 \%$ ) i od 20 do 30 godina ( $\mathrm{N}=33,28,7 \%)$. Najmanji broj ispitanika ima radni staž veći od 30 godina $(N=6,5,2 \%)$.

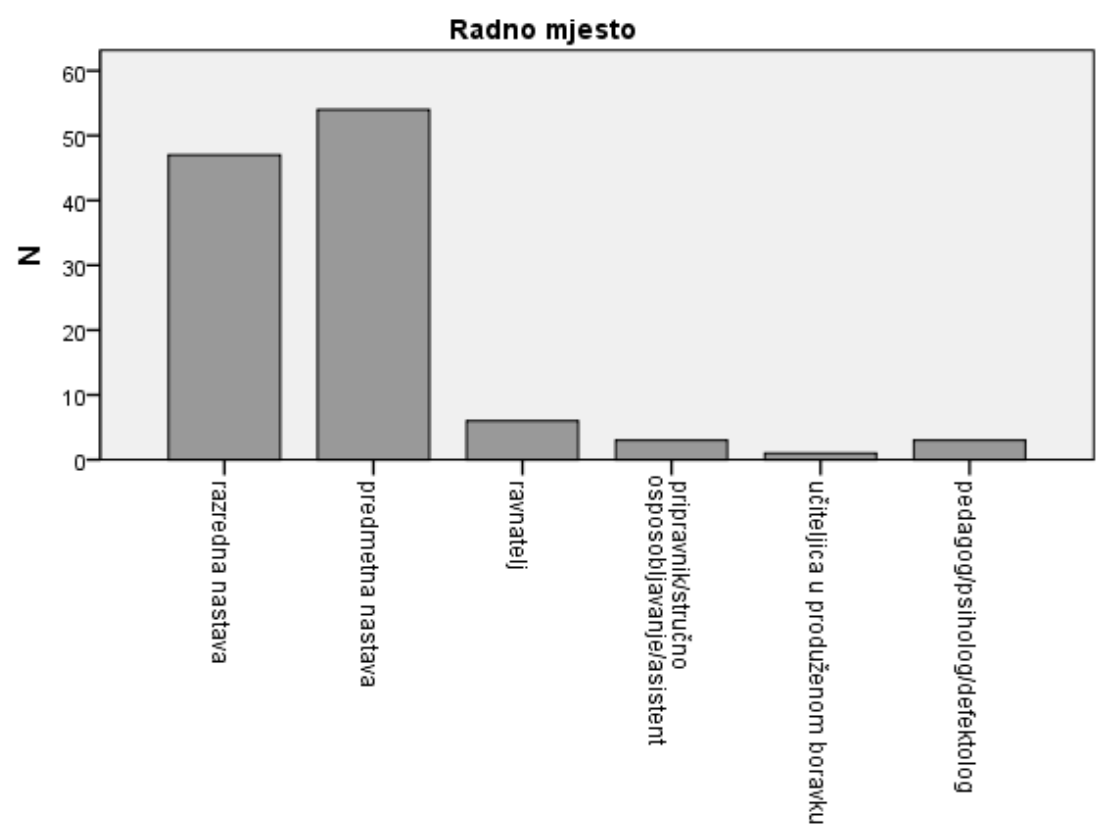

Grafikon 1. Prikaz uzorka istraživanja prema radnom mjestu $(\mathrm{N}=114)^{4}$

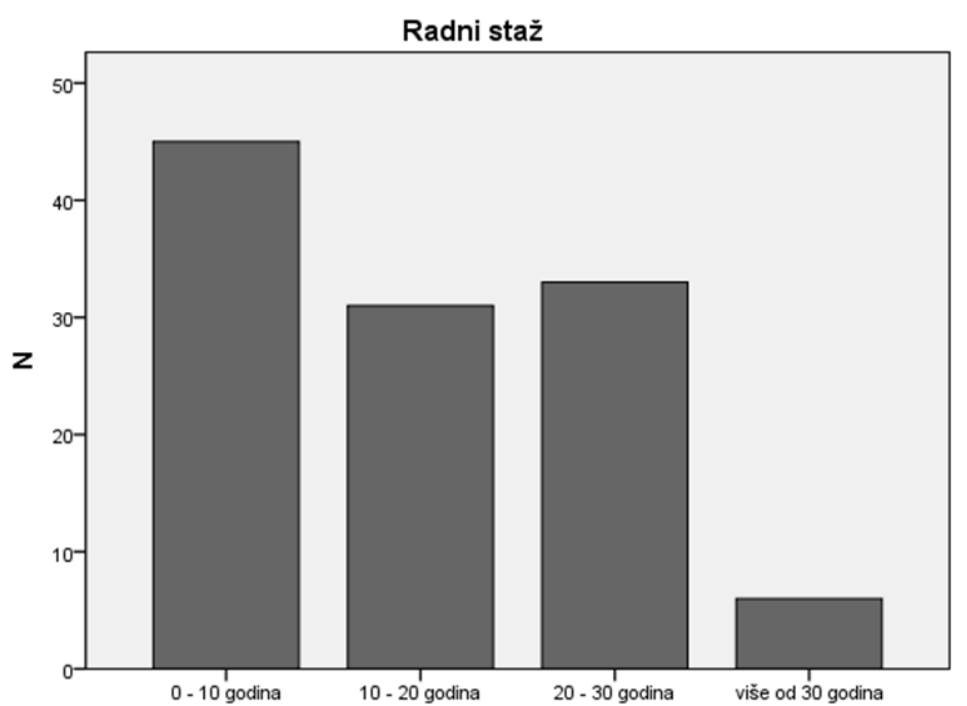

Grafikon 2. Prikaz uzorka istraživanja prema radnom stažu (N=115)

${ }^{4}$ Jedan ispitanik nije naveo svoje radno mjesto stoga je broj ispitanika analiziranih prema radnom mjestu za jedan manji od ukupnog broja ispitanika. 


\subsection{Metodologija istraživanja}

Za potrebe istraživanja kreiran je anketni upitnik u alatu Google Forms. Upitnik se sastojao od sedam pitanja zatvorenog tipa s ponuđenim odgovorima. Prikupljeni rezultati obrađeni su programom SPSS Statistics 20. Korištene su deskriptivne analize i Hi-kvadrat testovi za testiranje postavljenih hipoteza.

Cilj istraživanja bio je ispitati postojanje razlika u odnosu na radno mjesto i radni staž odgojnoobrazovnih djelatnika i njihovih dosadašnjih spoznaja $\mathrm{i}$ iskustava o Erasmus+ projektu, eTwinning mobilnostima i TCA seminarima.

$U$ istraživanju se polazilo od sljedećih hipoteza:

$H 1$ : Učitelji predmetne nastave prednjače $u$ uključenosti u Erasmus+ mobilnosti u odnosu na ostale odgojno-obrazovne djelatnike.

H2: Odgojno-obrazovni djelatnici radnog staža od 10 do 30 godina imaju najviše iskustva u Erasmus+ mobilnostima $u$ odnosu na starije kolege.

H3: Mlađi odgojno-obrazovni djelatnici informiraniji su o mogućnostima i natječajima Erasmus+ programa nego stariji djelatnici.

H4: Mlađi odgojno-obrazovni djelatnici imaju više preferencija za sudjelovanjem u Erasmus+ programima u odnosu na starije djelatnike.

\section{Rezultati i rasprava}

Većina naših ispitanika nije do sada sudjelovala niti u Erasmust programima (Nukupno=93, 81,6\%), niti u eTwinning mobilnostima ili TCA seminarima (Nukupno=93, 81,6\%). Analizirajući radna mjesta i sudjelovanje u spomenutim programima (Tablica 1. i Tablica 2.) vidimo da je nešto veći postotak učitelja predmetne nastave sudjelovao u Erasmus+ programima nego učitelja razredne nastave (NPN=12, 10,5\%; $N R N=7,6,1 \%$ ). Dva od šest anketiranih ravnatelja sudjelovalo je $u$ Erasmust programima i/ili eTwinning mobilnostima ili TCA seminarima.

Niti jedan pedagog/psiholog/defektolog, učiteljica u produženom boravku niti asistent/pripravnik/stručno osposobljavanje nisu sudjelovali u Erasmust programima. Jedan pedagog/psiholog/defektolog sudjelovao je $u$ eTwinning mobilnosti ili TCA seminaru. lako je najviše učitelja predmetne nastave sudjelovalo $u$ Erasmus+ projektima dobivena razlika nije statistički značajna stoga odbacujemo našu prvu hipotezu (H1) te zaključujemo da radno mjesto ne utječe na uključivanje u Erasmus+ projekte. Naša prva hipoteza formulirana je s pretpostavkom da će učitelji koji rade sa starijim učenicima biti odlučniji i spremniji na odlazak u inozemstvo od učitelja koji rade s mlađim učenicima.

\begin{tabular}{ccc|c}
\hline & & \multicolumn{2}{c}{ Sudjelovanje u Erasmus+ projektima } \\
\cline { 3 - 4 } & & da & ne \\
& & $\mathrm{N}(\%)$ & $\mathrm{N}(\%)$ \\
\cline { 2 - 4 } & razredna nastava & $7(6,1)$ & $40(35,1)$ \\
\cline { 2 - 4 } madno & predmetna nastava & $12(10,5)$ & $42(36,8)$ \\
\cline { 2 - 4 } & ravnatelj & $2(1,8)$ & $4(3,5)$ \\
\cline { 2 - 4 } & osposobljavanje/asistent & $0(0,0)$ & $3(2,6)$ \\
\cline { 2 - 4 } & učiteljica u produženom boravku & $0(0,0)$ & $1(0,9)$ \\
\cline { 2 - 4 } & pedagog/psiholog/defektolog & $0(0,0)$ & $3(2,6)$
\end{tabular}

Tablica 1. Prikaz podataka o sudjelovanju odgojno-obrazovnih djelatnika u Erasmus+ programima prema radnom $\mathrm{mjestu}(\mathrm{N}=114$, $x 2=3,377, p=0,642)$ 


\begin{tabular}{|c|c|c|c|}
\hline & & \multicolumn{2}{|c|}{$\begin{array}{c}\text { Sudjelovanje u eTwinning } \\
\text { mobilostima ili TCA seminarima }\end{array}$} \\
\hline & & $\begin{array}{c}\text { da } \\
\mathrm{N}(\%)\end{array}$ & $\begin{array}{c}\text { ne } \\
\mathrm{N}(\%)\end{array}$ \\
\hline \multirow{6}{*}{$\begin{array}{l}\text { Radno } \\
\text { mjesto }\end{array}$} & razredna nastava & $11(9,6)$ & $36(31,6)$ \\
\hline & predmetna nastava & $7(6,1)$ & $47(41,2)$ \\
\hline & ravnatelj & $2(1,8)$ & $4(3,5)$ \\
\hline & $\begin{array}{c}\text { pripravnik/stručno } \\
\text { osposobljavanje/asistent }\end{array}$ & $0(0,0)$ & $3(2,6)$ \\
\hline & učiteljica u produženom boravku & $0(0,0)$ & $1(0,9)$ \\
\hline & pedagog/psiholog/defektolog & $1(0,9)$ & $2(1,8)$ \\
\hline
\end{tabular}

Tablica 2. Prikaz podataka o sudjelovanju odgojno-obrazovnih djelatnika u eTwinning mobilnostima i TCA seminarima organiziranim od strane Agencije za mobilnost i programe EU, prema radnom mjestu $(N=114, \chi 2=4,082, p=0,538)$

Pogledamo li radni staž naših ispitanika (Tablica 3 i Tablica 4) vidimo da najveći broj ispitanika radnog staža od 10 do 20 godina ima iskustva u sudjelovanju u Erasmus+ programima $\left(\mathrm{N}_{10-20 \text { godina radnog staža }}=9,7,8 \%\right)$. Nešto je veći broj ispitanika radnog staža do 10 godina sudjelovao $u$ eTwinning mobilnostima i TCA seminarima $\left(\mathrm{N}_{0}\right.$ 10godina radnog staža $=8,7,0 \%$ ). Nažalost, većina ispitanika radnog staža većeg od 30 godina nije sudjelovala niti u Erasmus+ projektima niti u eTwinning mobilnostima ili TCA seminarima. Provedenom analizom vidimo da većina odgojno- obrazovnih djelatnika radnog staža od 10 do 30 godina ima iskustva s Erasmus+ projektima no dobivena razlika nije statistički značajna, stoga ne možemo potvrditi drugu postavljenu hipotezu (H2). H2 postavljena je s početnom mišlju da su najmlađi odgojno-obrazovni djelatnici fokusirani na pripremanje za polaganje svog stručnog ispita te uhodavanje u odgojno-obrazovni rad, a djelatnici $s$ više od 30 godina radnog staža nisu dovoljno motivirani za odricanje koje sa sobom nosi sudjelovanje u Erasmus+ projektima.

\begin{tabular}{cc|c|c}
\hline & & \multicolumn{2}{c}{ Sudjelovanje u Erasmus+ projektima } \\
\cline { 3 - 4 } & & da & ne \\
& & $\mathrm{N}(\%)$ & $\mathrm{N}(\%)$ \\
\hline \multirow{2}{*}{ Radni } & 0-10 godina & $5(4,3)$ & $40(34,8)$ \\
\cline { 2 - 4 } staž & 10-20 godina & $9(7,8)$ & $22(19,1)$ \\
\cline { 2 - 4 } & 20-30 godina & $6(5,2)$ & $27(23,5)$ \\
\cline { 2 - 4 } & više od 30 godina & $1(0,9)$ & $5(4,3)$
\end{tabular}

Tablica 3. Prikaz podataka o sudjelovanju odgojno-obrazovnih djelatnika u Erasmus+ programima prema radnom stažu (N=115, $\chi 2$ $=3,961, p=0,266)$ 


\begin{tabular}{cc|c|c}
\hline & & \multicolumn{2}{r}{$\begin{array}{r}\text { Sudjelovanje u eTwinning mobilnostima } \\
\text { ili TCA seminarima }\end{array}$} \\
\cline { 3 - 4 } & & da & ne \\
& & $\mathrm{N}(\%)$ & $\mathrm{N}(\%)$ \\
\hline \multirow{2}{*}{ Radni } & 0-10 godina & $8(7,0 \%)$ & $37(32,2 \%)$ \\
\cline { 2 - 4 } & 10-20 godina & $6(5,2)$ & $25(21,7)$ \\
\cline { 2 - 4 } & 20-30 godina & $7(6,1)$ & $26(22,6)$ \\
\cline { 2 - 4 } & više od 30 godina & $0(0,0)$ & $6(5,2)$
\end{tabular}

Tablica 4. Prikaz podataka o sudjelovanju odgojno-obrazovnih djelatnika u eTwinning mobilnostima i TCA seminarima prema radnom stažu $(\mathrm{N}=115, \chi 2=1,565, \mathrm{p}=0,667)$

lako je ukupan broj naših sudionika koji su sudjelovali u nekoj vrsti mobilnosti vrlo mali, rezultati istraživanja pokazuju da bi većina anketiranih odgojno-obrazovnih djelatnika željela sudjelovati u Erasmus+ projektima (Grafikon 3).

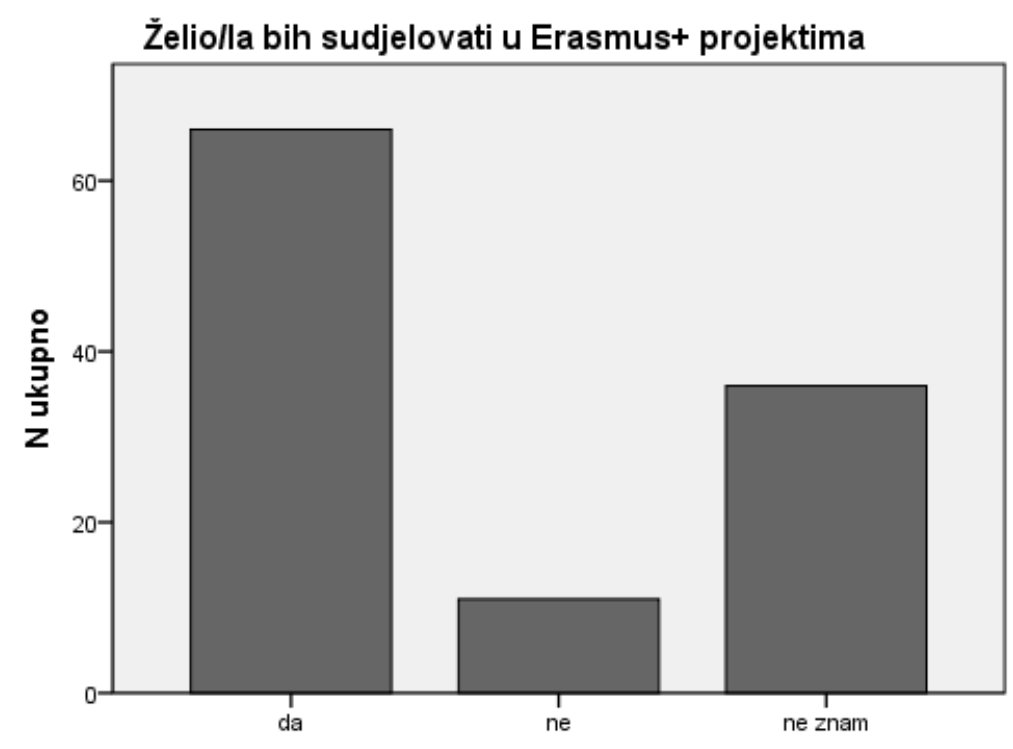

Grafikon 3. Prikaz preferencija ispitanika za sudjelovanjem u Erasmus+ projektima ( $N=115)$

Analiziramo li preferencije za sudjelovanjem u Erasmus+ programima prema radnom mjestu uočavamo da učitelji predmetne nastave pokazuju najveći interes (Tablica 5). Najveći broj odgojno-obrazovnih radnika sa stažem do 10 godina ima želju sujelovati u Erasmus+ programima (Tablica 6) što potvrđuje H4. U sljedećim istraživanjima bilo bi zanimljivo provjeriti razloge malog sudjelovanja odgojnoobrazovnih djelatnika u Erasmus+ ili eTwinning mobilnostima jer, kao što vidimo, motivacija odgojno-obrazovnih djelatnika nije upitan faktor. 


\begin{tabular}{|c|c|c|c|c|}
\hline & & \multicolumn{3}{|c|}{ Želio/la bih sudjelovati u Erasmus+ projektima } \\
\hline & & $\begin{array}{c}\text { da } \\
\mathrm{N}(\%)\end{array}$ & $\begin{array}{c}\text { ne znam } \\
\mathrm{N}(\%)\end{array}$ & $\begin{array}{c}\text { ne } \\
\mathrm{N}(\%) \\
\end{array}$ \\
\hline \multirow{6}{*}{$\begin{array}{l}\text { Radno } \\
\text { mjesto }\end{array}$} & razredna nastava & $27(24,1)$ & $13(11,6)$ & $5(4,5)$ \\
\hline & predmetna nastava & $30(26,8)$ & $19(17,01)$ & $5(4,5)$ \\
\hline & ravnatelj & $5(4,5)$ & $1(0,9)$ & $0(0,0)$ \\
\hline & $\begin{array}{c}\text { pripravnik/stručno } \\
\text { osposobljavanje/asistent }\end{array}$ & $1(0,9)$ & $2(1,8)$ & $0(0,0)$ \\
\hline & učiteljica u produženom boravku & $1(0,9)$ & $0(0,0)$ & $0(0,0)$ \\
\hline & pedagog/psiholog/defektolog & $2(1,8)$ & $0(0,0)$ & $1(0,9)$ \\
\hline
\end{tabular}

Tablica 5. Prikaz podataka o željama za sudjelovanjem odgojno-obrazovnih djelatnika u Erasmus+ programima prema radnom mjestu $(N=112, \chi 2=7,344, p=0,693)$

\begin{tabular}{cc|c|c|c}
\hline & & \multicolumn{3}{c}{ Želio/la bih sudjelovati u Erasmus projektima } \\
\cline { 3 - 5 } & & $\mathrm{da}$ & ne znam & ne \\
& & $\mathrm{N}(\%)$ & $\mathrm{N}(\%)$ & $\mathrm{N}(\%)$ \\
\hline \multirow{3}{*}{ Radni } & 0-10 godina & $29(25,7)$ & $14(12,4)$ & $2(1,8)$ \\
\cline { 2 - 5 } staž & 10-20 godina & $17(15,0)$ & $10(8,8)$ & $4(3,5)$ \\
\cline { 2 - 5 } & 20-30 godina & $16(14,2)$ & $11(9,7)$ & $4(3,5)$ \\
\cline { 2 - 5 } & više od 30 godina & $4(3,5)$ & $1(0,9)$ & $1(0,9)$
\end{tabular}

Tablica 6. Prikaz podataka o željama za sudjelovanjem odgojno-obrazovnih djelatnika u Erasmus+ programima prema radnom stažu $(N=115, \chi 2=3,465, p=0,749)$

Neka do sada provedena istraživanja (Berg, 2014, Zühal Endes, 2015) pokazuju da su sudionici Erasmus+ programa nezadovoljni dobivenim informacijama o Erasmus+ projektima i njihovim obvezama prije, tijekom i nakon sudjelovanja $u$ programu stoga smo naše ispitanike upitali znaju li gdje mogu pronaći potrebne informacije za sudjelovanje u Erasmust projektima te jesu li upoznati s Erasmus+ programom i mogućnostima koje se nude odgojno-obrazovnim djelatnicima (Tablica 7 i Tablica 8). Polovina naših ispitanika upoznata je $s$ Erasmus+ programom i njegovim mogućnostima te znaju gdje mogu pronaći sve potrebe informacije i natječaje.

Željeli smo provjeriti razlikuje li se informiranost odgojno-obrazovnih djelatnika o
Erasmus+ programa u odnosu na njihov radni staž (Tablica 9 i Tablica 10). Rezultati pokazuju da je veliki broj odgojno-obrazovnih djelatnika radnog staža više od 20 godina upoznat s Erasmus+ programom i njegovim mogućnostima te znaju gdje mogu pronaći informacije i natječaje za sudjelovanje $u$ Erasmust programu, što je $u$ suprotnosti s ustaljenim mišljenjem da su mlađi ljudi informatički i informacijski pismeniji od starijih. Iznenađuje podatak da veliki broj odgojno-obrazovnih djelatnika sa stažem do 10 godina (No-10 godina radnog staža $=16,14,2 \%$ ) ne zna gdje mogu pronaći informacije i natječaje za sudjelovanje u Erasmus+ programima.

Analizom dobivenih rezultata utvrđeno je da su učitelji djelomično upoznati $s$ Erasmus+ 
programom i mogućnostima koje nudi, no u nekom od oblika Erasmus+ programa. nažalost vrlo mali postotak učitelja je i sudjelovao

\begin{tabular}{|c|c|c|c|c|}
\hline & & \multicolumn{3}{|c|}{$\begin{array}{l}\text { Upoznat/a sam s Erasmus+ programom i mogućnostima koje se } \\
\text { nude učiteljima osnovnih škola }\end{array}$} \\
\hline & & $\begin{array}{c}\text { da } \\
\mathrm{N}(\%)\end{array}$ & $\begin{array}{l}\text { djelomično } \\
\mathrm{N}(\%)\end{array}$ & $\begin{array}{c}\text { ne } \\
\mathrm{N}(\%)\end{array}$ \\
\hline \multirow{6}{*}{$\begin{array}{l}\text { Radno } \\
\text { mjesto }\end{array}$} & razredna nastava & $28(24,6)$ & $13(11,4)$ & $6(5,3)$ \\
\hline & predmetna nastava & $23(20,2)$ & $24(21,1)$ & $7(6,1)$ \\
\hline & ravnatelj & $5(4,4)$ & $1(0,9)$ & $0(0,0)$ \\
\hline & $\begin{array}{l}\text { pripravnik/stručno } \\
\text { osposobljavanje/asistent }\end{array}$ & $0(0,0)$ & $3(2,6)$ & $0(0,0)$ \\
\hline & učiteljica u produženom boravku & $1(0,9)$ & $0(0,0)$ & $0(0,0)$ \\
\hline & pedagog/psiholog/defektolog & $1(0,9)$ & $1(0,9)$ & $1(0,9)$ \\
\hline
\end{tabular}

Tablica 7. Prikaz podataka o upoznatosti odgojno-obrazovnih djelatnika s mogućnostima Erasmus+ programa prema radnom jestu $(N=114, \chi 2=13,404, p=0,202)$

\begin{tabular}{|c|c|c|c|}
\hline & & \multicolumn{2}{|c|}{$\begin{array}{c}\text { Znam gdje mogu pronaći informacije i } \\
\text { natječaje za sudjelovanje u programu } \\
\text { Erasmus+ }\end{array}$} \\
\hline & & $\begin{array}{c}\text { da } \\
\mathrm{N}(\%) \\
\end{array}$ & $\begin{array}{c}\text { ne } \\
\mathrm{N}(\%) \\
\end{array}$ \\
\hline \multirow{6}{*}{$\begin{array}{l}\text { Radno } \\
\text { mjesto }\end{array}$} & razredna nastava & $30(26,8)$ & $15(13,4)$ \\
\hline & predmetna nastava & $37(33,0)$ & $17(15,2)$ \\
\hline & ravnatelj & $5(4,5)$ & $1(0,9)$ \\
\hline & $\begin{array}{c}\text { pripravnik/stručno } \\
\text { osposobljavanje/asistent }\end{array}$ & $1(0,9)$ & $2(1,8)$ \\
\hline & učiteljica u produženom boravku & $1(0,9)$ & $0(0,0)$ \\
\hline & pedagog/psiholog/defektolog & $2(1,8)$ & $1(0,9)$ \\
\hline
\end{tabular}

Tablica 8. Prikaz podataka o spoznajama odgojno-obrazovnih djelatnika o mjestima pronalaska informacija i natječaja za sudjelovanje $u$ Erasmus+ programima $(N=114, \chi 2=2,814, p=0,729)$ 


\begin{tabular}{|c|c|c|c|c|}
\hline & & \multicolumn{3}{|c|}{$\begin{array}{c}\text { Upoznatost s Erasmus+ programom i njegovim } \\
\text { mogućnostima }\end{array}$} \\
\hline & & $\begin{array}{c}\text { da } \\
\mathrm{N}(\%)\end{array}$ & $\begin{array}{c}\text { djelomično } \\
\mathrm{N}(\%) \\
\end{array}$ & $\begin{array}{c}\text { ne } \\
\mathrm{N}(\%)\end{array}$ \\
\hline \multirow{4}{*}{$\begin{array}{l}\text { Radni } \\
\text { staž }\end{array}$} & $0-10$ godina & $20(17,4)$ & $17(14,8)$ & $8(7,0)$ \\
\hline & 10-20 godina & $17(14,8)$ & $14(12,2)$ & $0(0,0)$ \\
\hline & $20-30$ godina & $18(15,7)$ & $10(8,7)$ & $5(4,3)$ \\
\hline & više od 30 godina & $3(2,6)$ & $2(1,7)$ & $1(0,9)$ \\
\hline
\end{tabular}

Tablica 9. Prikaz podataka o upoznatosti odgojno-obrazovnih djelatnika s mogućnostima Erasmus+ programa prema radnom stažu $\left(\mathrm{N}=115, \chi^{2}=6,797, \mathrm{p}=0,340\right)$

\begin{tabular}{cc|c|c}
\hline & & \multicolumn{2}{c}{$\begin{array}{c}\text { Znam gdje mogu pronaći informacije i } \\
\text { natječaje za Erasmus+ projekte }\end{array}$} \\
\cline { 3 - 4 } & & $\mathrm{da}$ & ne \\
& & $\mathrm{N}(\%)$ & $\mathrm{N}(\%)$ \\
\hline \multirow{3}{*}{ Radni } & 0-10 godina & $29(25,7)$ & $16(14,2)$ \\
\cline { 3 - 4 } staž & 10-20 godina & $24(21,2)$ & $7(6,2)$ \\
\cline { 2 - 4 } & 20-30 godina & $20(17,7)$ & $11(9,7)$ \\
\cline { 2 - 4 } & više od 30 godina & $3(2,7)$ & $3(2,7)$
\end{tabular}

Tablica 10. Prikaz podataka o znanju odgojno-obrazovnih djelatnika o mjestima pronalaska informacija i natječaja za Erasmus+ programe prema radnom stažu $(\mathrm{N}=113, \chi 2=2,533, \mathrm{p}=0,469)$

\section{Zaključak}

Da bi odgojno-obrazovni proces bio što uspješniji i učinkovitiji, a nastavne metode inovativne $\mathrm{i}$ suvremene, najvažnija je edukacija i usavršavanje obrazovnih djelatnika koji su glavni kreatori svakog nastavnog procesa. Upravo zahvaljujući Erasmus+ programu Europske unije, obrazovni sustavi imaju mogućnost unaprijediti obrazovanje i upravljati promjenama i inovacijama te odigrati ključnu ulogu u suočavanju s izazovima modernog doba. Program Erasmus+ pruža svim ravnateljima, stručnim timovima i učiteljima koje zanima rad u inozemstvu mogućnost da se uključe u preoblikovanje kurikuluma i na taj način doprinesu unapređenju obrazovanja u Europi.
Ovim se radom željela prikazati informiranost $\mathrm{i}$ stupanj sudjelovanja osnovnoškolskih učitelja sjeverozapadne Hrvatske u Erasmus+ programu. $\mathrm{U}$ istraživanju je sudjelovalo ukupno 115 učitelja iz osnovnih škola na području Varaždinske i Koprivničko-križevačke županije. lako 51\% ispitanika navododi da su upoznati s Erasmus+ programom i mogućnostima koje se nudi, dok $38,3 \%$ ispitanika smatra da su djelomično upoznati s istim, u Erasmus KA1 ili KA2 projektima sudjelovalo je svega $18,4 \%$ učitelja, što je poražavajući postotak. lako je najviše učitelja predmetne nastave sudjelovalo u Erasmus+ projektima dobivena razlika nije statistički značajna stoga odbacujemo našu prvu hipotezu (H1 - učitelji predmetne nastave prednjače u uključenosti u Erasmus+ mobilnosti u odnosu na 
ostale odgojno-obrazovne djelatnike) te zaključujemo da radno mjesto ne utječe na uključivanje u Erasmus+ projekte. lako rezultati provedene analize pokazuju da najviše iskustva $s$ Erasmus+ projektima imaju odgojno-obrazovni djelatnici s 10 do 20 godina radnog staža, dobivena razlika nije statistički značajna, stoga ne možemo potvrditi drugu postavljenu hipotezu ( $\mathrm{H} 2$ - Odgojno-obrazovni djelatnici radnog staža od 10 do 30 godina imaju najviše iskustva u Erasmus+ mobilnostima u odnosu na starije kolege.) Od ukupnog broja ispitanika, njih $64,99 \%$ zna gdje može pronaći sve potrebne informacije i natječaje za prijavu za sudjelovanje u programu Erasmus+, a ohrabruje i činjenica da više od polovine ispitanika želi sudjelovati u Erasmus+ projektima, a $31,9 \%$ je još neodlučno. Najviše preferencija za sudjelovanje u Erasmus+ projektima imaju mlađi ispitanici čime se potvrđuje H4 - mlađi odgojnoobrazovni djelatnici imaju više preferencija za sudjelovanjem u Erasmus+ programima u odnosu na starije djelatnike. Rezultati pokazuju i da je veliki broj odgojno-obrazovnih djelatnika radnog staža više od 20 godina upoznat s Erasmus+ programom i njegovim mogućnostima te znaju gdje mogu pronaći informacije i natječaje za sudjelovanje u Erasmust programu, što je $u$ suprotnosti s ustaljenim mišljenjem da su mlađi ljudi informatički i informacijski pismeniji od starijih čime se opovrgava i naša treća hipoteza H3 - mlađi odgojno-obrazovni djelatnici informiraniji su o mogućnostima i natječajima Erasmus+ programa nego stariji djelatnici.

Temeljem dobivenih rezultata istraživanja vidljivo je da postoji interes za sudjelovanje učitelja osnovnih škola u Erasmus+ programu, no valjalo bi dodatno istražiti zbog kojih razloga učitelji ne realiziraju svoje želje. Prvi, a možda i najvažniji korak prema uspješnom sudjelovanju u Erasmust programu je zasigurno dobra informiranost i upoznatost svih odgojnoobrazovnih djelatnika s mogućnostima, dobrobitima i pogodnostima koje program nudi. Dobar primjer uspješnog sudjelovanja u Erasmus+ projektima zasigurno je primjer I. osnovne škole Varaždin.

\section{Literatura}

Agencija za mobilnost i programe Europske unije (2016). Erasmus+: Praktičan vodič za ravnatelje i stručne timove u školama. Preuzeto 24. 04.2018. sa http://www.mobilnost.hr/cms_files/2016/11/ 1480086278_vodic-hr-web.pdf.

Agencija za mobilnost i programe Europske unije (2018). Rezultati sudjelovanja Republike Hrvatske u programima Erasmust i Obzor 2020. do lipnja 2018. Preuzeto 24. 04. 2018 sa http://www.mobilnost.hr/hr/novosti/rezultati -sudjelovanja-republike-hrvatske-uprogramima-erasmus-i-obzor-2020-do-lipnja2018.

Agencija za mobilnost i programe Europske unije (2018). Erasmus+: Opće informacije. Preuzeto $24 . \quad 04.2018 .2$ sa http://www.mobilnost.hr/hr/sadrzaj/erasmus -opce-informacije.

Berg, V. (2014). Evaluation of the Outcome of European Students - Teachers' Participation in the Erasmus Exchange Programme (20082011): A Survey of Students' Knowledge, Thoughts and Feelings before and after their Erasmus Exchange. Journal of the EuropeanTeacher Education Network, 9, 3345.

European Commission (2006). Lifelong learning': a new education and training programme to build the Knowledge Society. Preuzeto 15. 12. 2018. sa http://europa.eu/rapid/pressrelease_IP-06-1478_en.htm.

European Commission (2018). Erasmust. What is Erasmus+? Preuzeto 9. 04.2018 . sa https://ec.europa.eu/programmes/erasmusplus/about_en.

Zühal Endes, Y. (2015). Overseas education process of outgoing students within The Erasmus Exchange Programme. Procedia Social and Behavioral Sciences, 174, 14081414. 


\title{
Participation of Primary School Teachers in the Erasmus+ Programmes
}

\begin{abstract}
Erasmust is the biggest EU programme that includes education, training, youth and sport and it offers multiple possibilities for students and educational institutions involved in education, training and sport. With the presumption that the teachers aren't adequately informed and that most of them haven't participated in Erasmus+ projects, the objective of this research was to examine the awareness and participation of primary school teachers in northwest Croatia under the Erasmust programme. The research was carried out in the school year 2017/2018 on the sample of 115 educational professionals from 15 primary schools in northwest Croatia. Although 49.6\% of the subjects consider that they are well informed about Erasmust programme and the possibilities which are offered to the primary school teachers, the results of the research show that the majority, $81.6 \%$ of the subjects, haven't participated in Erasmus+ programmes, eTwinning mobilities or in TCA seminars organised by the Agency for Mobility and EU Programmes. Only $18.4 \%$ of the teachers have participated in Erasmus $K A 1$ or KA2 projects, and $18.3 \%$ in TCA seminars or eTwinning mobilities.
\end{abstract}

Keywords: innovations in education; staff mobilities; strategic partnerships; school exchange. 